\title{
Heterogeneous material distribution, an important reason for generation of strain-localized mylonite and frictional slip zones in the Hidaka metamorphic belt, Hokkaido, Japan
}

\author{
Hidemi Tanaka ${ }^{1}, K_{\text {Koji Shimada }}{ }^{1}$, Tsuyoshi Toyoshima ${ }^{2}$, Tomohiro Obara ${ }^{3}$, and Tadafumi Niizato ${ }^{4}$ \\ ${ }^{1}$ Depertment of Earth and Planetary Science, Graduate school of Science, University of Tokyo, Bunkyo, Tokyo 113-0033, Japan \\ ${ }^{2}$ Graduate School of Science and Technology, Niigata University, Niigata 950-2181, Japan \\ ${ }^{3}$ Japan Oil Development Co., Ltd., Tokyo 104-0033, Japan \\ ${ }^{4}$ Horonobe Underground Research Center, Japan Nuclear Cycle Development Institute, Horonobe, Hokkaido 098-3297, Japan
}

(Received June 24, 2004; Revised November 22, 2004; Accepted December 6, 2004)

\begin{abstract}
Lithological heterogeneity of low P/T metamorphic rocks in southern area of Hidaka metamorphic belt (HMB) was formed through historical development of HMB while these rocks had been laid in ductile lower crust. Many strain-localized mylonite zones $(<100 \mathrm{~m}$ in thickness) are preferentially developed within S-type tonalite and pelitic gneiss, which are characterized by a large modal amount of phyllosilicates (biotite + muscovite + chlorite) and quartz, compared to other lithofacies in HMB. Mylonitic foliations are more conspicuous with close to the center of the shear zone associated with increase in amounts of phyllosilicate minerals, indicating fluidenhanced weakening mechanisms were operated in plastic shear zones. Pseudotachylyte veins are observed exclusively in these mylonite zones, which were generated during exhumation stage of HMB. We conclude the seismic slip zones in southern HMB had been initiated in the ductile lower crust by concentration of localized plastic shear zones within the phyllosilicate- and quartz-rich lithofacies, which were heterogeneously formed by old metamorphic and magmatic events. Then these zones were further weakened by fluid-enhanced plastic deformation, and finally seismic slips occurred at the bottom of seismogenic upper crust, during exhumation of HMB.
\end{abstract}

Key words: Pseudotachylite, mylonite, Hidaka metaorphic belt, rupture generation mechanism.

\section{Introduction}

One of the fundamental questions for development of fault zones in seismological upper crust is inevitability of locations of the slip surfaces. One may suppose that preexisting weak surfaces/materials generated by local events such as magmatic intrusions, or by concentration of local tectonic stress are the possible explanations, because larger seismogenic faults developed within the complex and heterogeneous lithofacies are more common and universal. In order to examine this problem more in detail, we have investigated the exhumed fault zones exposed in the southern area of Hidaka metamorphic belt (HMB), Hokkaido, Japan. The southern HMB is appropriate to examine this problem because of following several reasons. (1) The latest metamorphic events (amphibolite facies; Osanai et al., 1997) are relatively new (Early Paleocene to Miocene; Komatsu et al., 1994; Owada et al., 1997). Thus less overprinting deformations are expected. (2) Detailed geological information on this area has been given by Obara (1997). (3) Lithology in this area is highly complex and seems to be appropriate to examine the effects of heterogeneity to the fault zone development. (4) Strain localized mylonite and pseudotachylyte layers are more frequently developed in this re-

Copy right(c) The Society of Geomagnetism and Earth, Planetary and Space Sciences (SGEPSS); The Seismological Society of Japan; The Volcanological Society of Japan; The Geodetic Society of Japan; The Japanese Society for Planetary Sciences; TERRAPUB. gion than northern and middle regions of HMB (Toyoshima et al., 2004). This paper describes possible genetic reasons of seismogenic fault zones through macro- to microscopic observations of lithofacies and fault zone rocks in southern HMB.

\section{Geological Settings of Southern HMB}

Geological structure of southern HMB is trending roughly $\mathrm{N}-\mathrm{S}$, dipping moderately to the east (Fig. 1). The HMB is bounded by the Hidaka Main Thrust (HMT) and adjoins to the Idonnappu meta-acretionary complex to the west. Minor syn- and anti-forms are observed along the area adjacent to HMT (Fig. 1). The metamorphic grade is basically highest along the western margin of southern HMB and gradually lowers to the east (Osanai et al., 1997). The HMB extends further to the east where nonmetamorphic sedimentary rocks are distributed. In the study area, the HMB is basically composed of two types of rocks. One is low-P/high-T type metamorphic rocks and another is huge volume of intrusive rocks. The former is composed of amphibolite and pelitic/psamitic gneiss. The latter is composed of (1) gabbronorite-hornblende gabbro, (2) hornblende-diorite/tonalite, (3) troctolite-olivine gabbro, and (4) huge amounts of S-type tonalite associated with minor amounts of I-type tonalite. The S-type tonalite is further subdivided into basal, lower and middle S-type tonalite, based on the difference of sequence and structural level of 

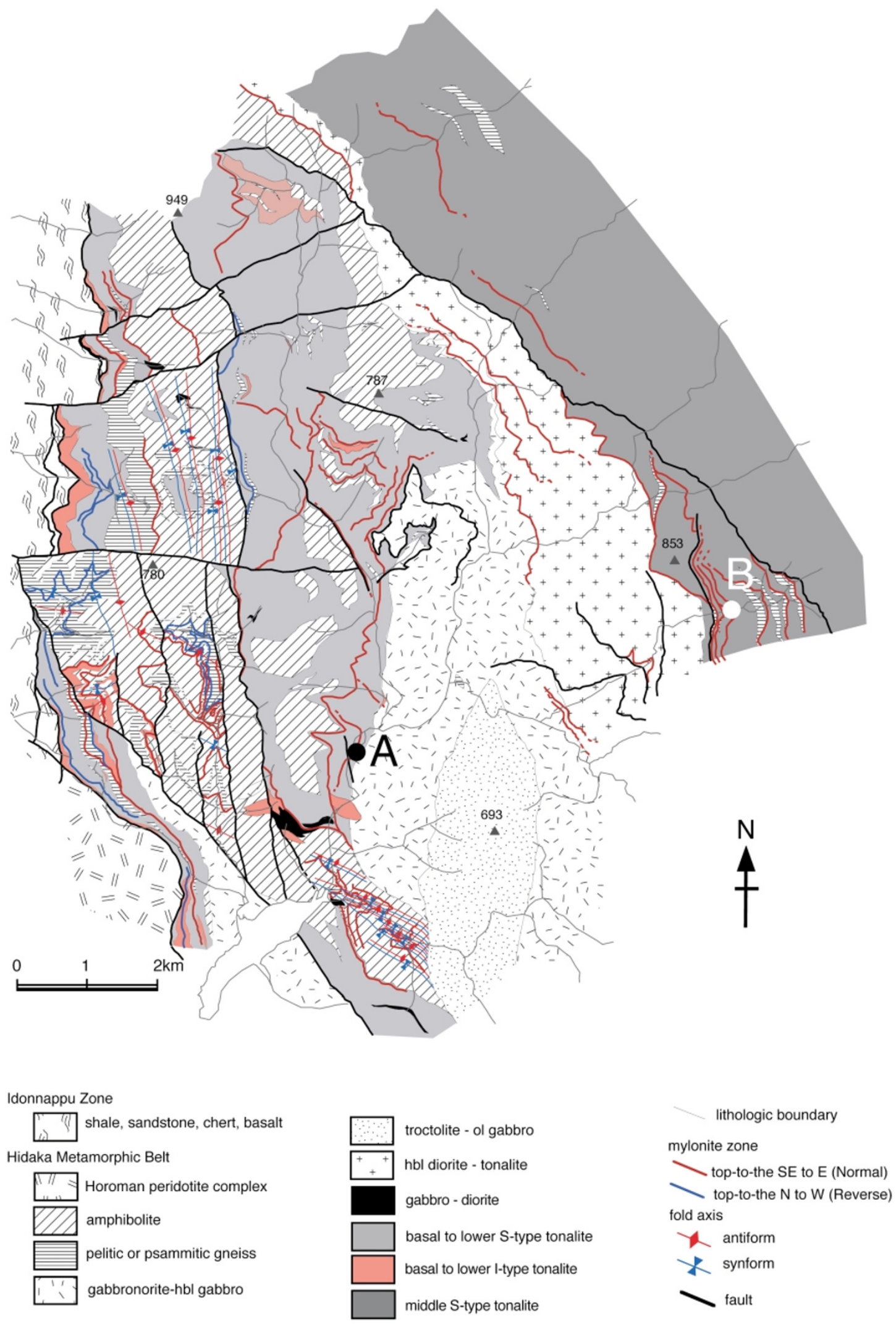

Fig. 1. Geological map of southern Hidaka metamorphic belt, after Obara (1997). Localized zones of mylonite are also shown by red and blue thin lines. A and B; Locations of well exposed localized shear zones. See text for explanations.

intrusion (Shimura et al., 1997). The metamorphic rocks are the oldest in this area, which were initially intruded by (1), and then by (2). They were further intruded by (3). The latest magmatic event was intrusion of (4) (Toyoshima
1991; Komatsu et al., 1994; Toyoshima et al., 1994; Osanai et al., 1997; Owada et al., 1997). The gneissosity developed in metamorphic rocks are almost parallel to the geological structure. In contrast, foliations do not develop in 

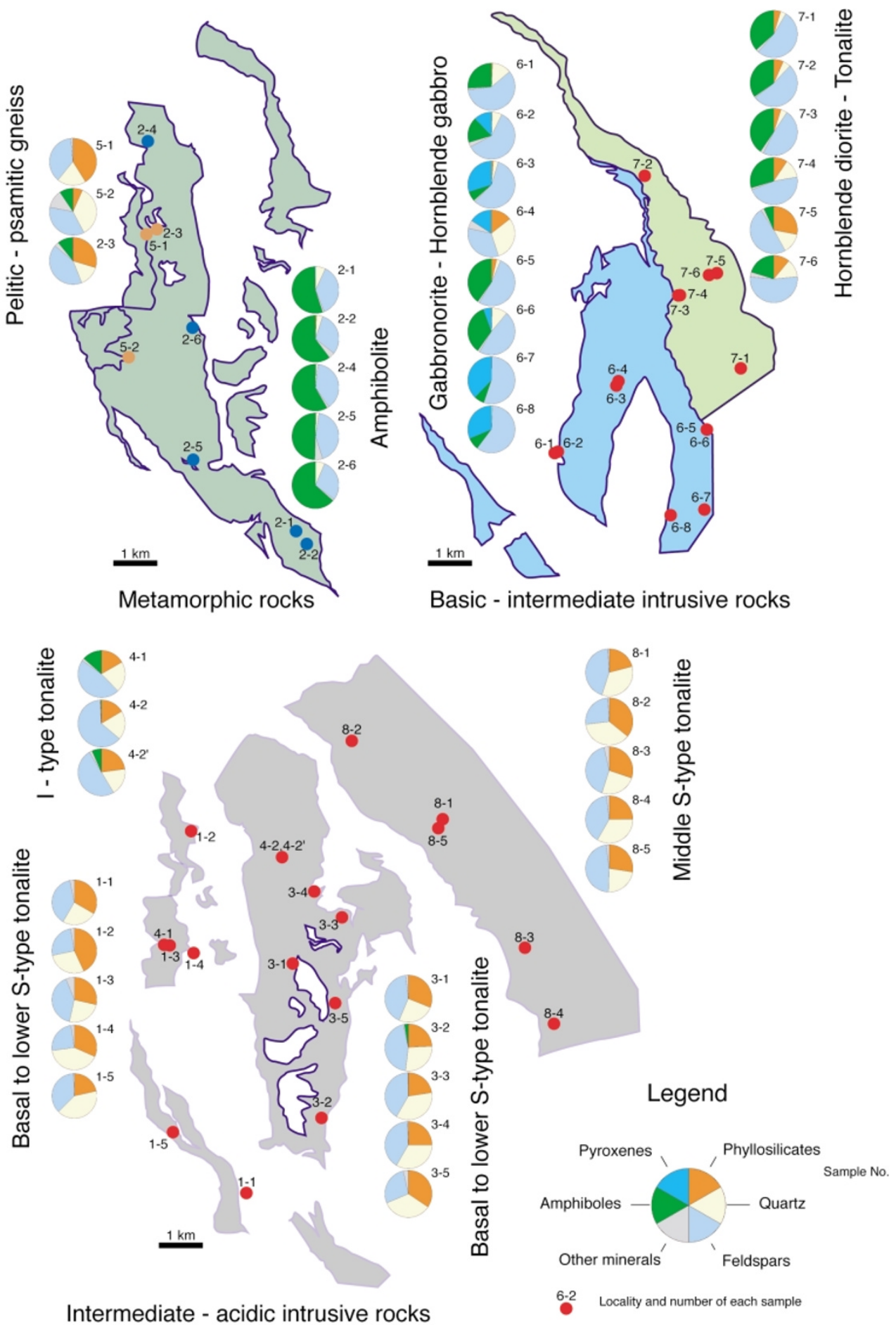

Fig. 2. Graphical presentation of mineral mode analysis. See text for detailed explanations.

the intrusive rocks showing homogeneous texture. It is obvious that the complex assemblage of lithofacies and geological structure, as shown in Fig. 1 was formed through evolution history of southern HMB while the metamorphic and igneous rocks were laid under granulite/amphibolite to higher green schist metamorphic conditions. Localized plastic shear zones overprint these metamorphic rocks and granitoids. These shear zones are generally less than 100 $\mathrm{m}$ in thickness, trending almost $\mathrm{N}-\mathrm{S}$, roughly parallel to the geological structure. Some of the large shear zones are shown in Fig. 1. Some brittle shear zones also exist in this area, especially along the lithological boundaries, which are drawn by thick lines in Fig. 1 .

\section{Mineral Mode Analysis}

The mineral mode analysis is performed in order to clarify whether concentration of mylonite zones is related to the mineral mode of lithofacies. Forty samples of fresh, non-deformed rocks are obtained from various lithofacies (Fig. 2). They are analyzed by point counter method under optical microscope (1000 points for each). The results are summarized in Table 1 and are graphi- 

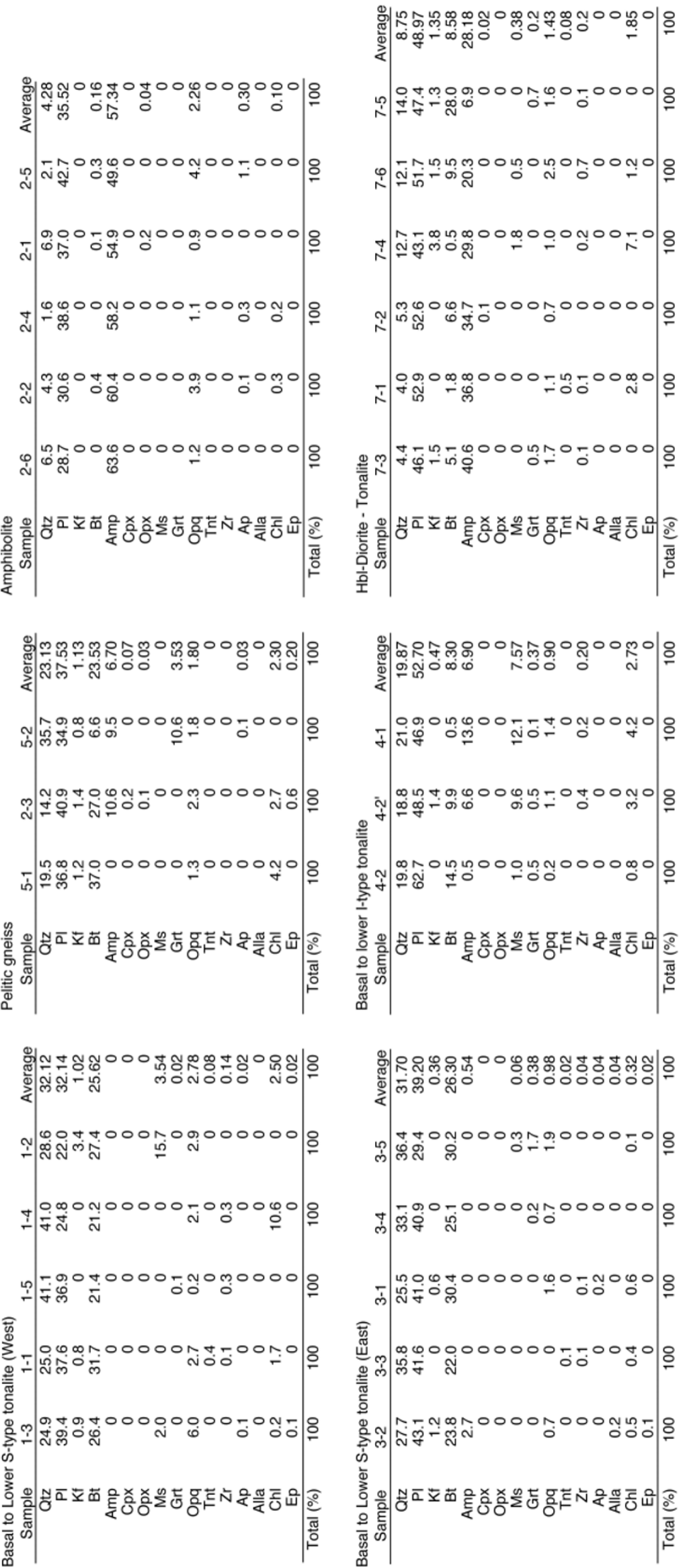

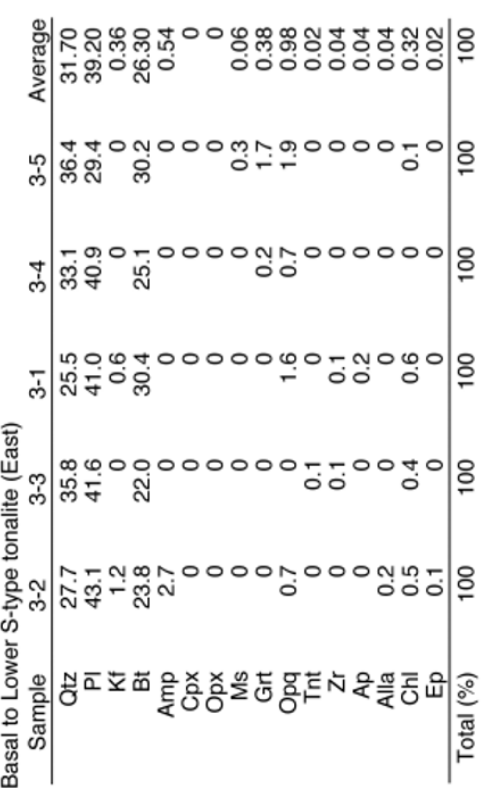

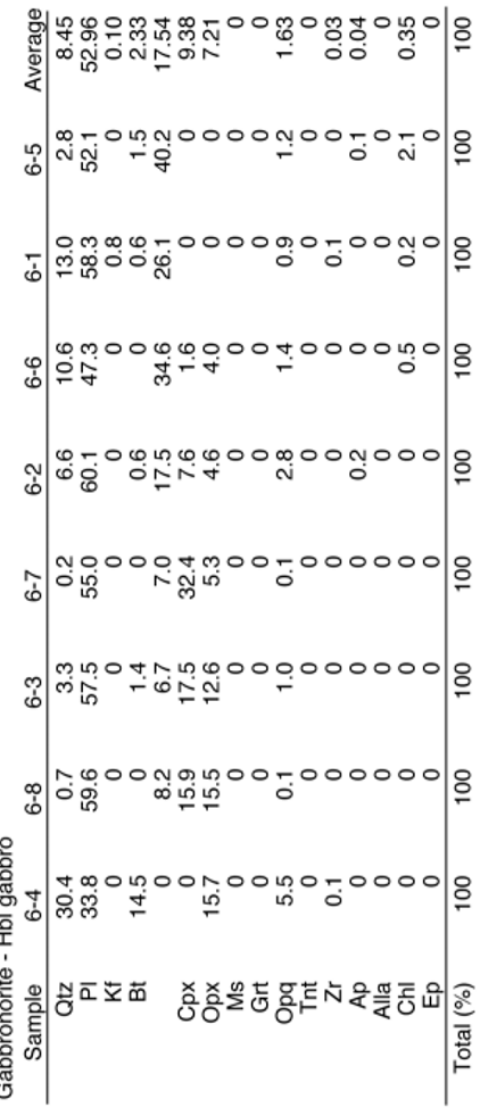

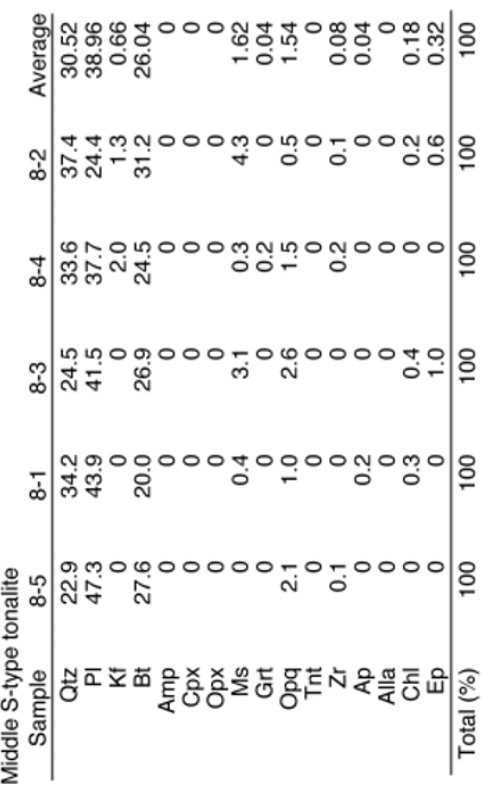


cally shown in Fig. 2. Although 16 minerals are listed in Table 1 for each sample, each categorized rock is composed more than $85 \%$ of three or four major minerals, as described below. Pelitic gneiss (2-3, 5-1 and 52 in Fig. 2) is composed of plagioclase (37.53\%), phyllosilicates (biotite+muscovite+chlorite, $25.83 \%$ ), quartz $(23.13 \%)$ and minor accessory minerals. Amphibolite (21 to 2-6) is mainly composed of amphiboles (57.34\%), plagioclase $(35.52 \%)$ and quartz $(4.28 \%)$. GabbronoriteHornblende gabbro (6-1 to 6-6) is composed of plagioclase $(52.96 \%)$, amphiboles $(17.54 \%)$, pyroxenes $(16.59 \%)$ and quartz $(8.45 \%)$. Hornblende diorite-tonalite (7-1 to $7-6)$ is composed of plagioclase $(48.97 \%)$, amphiboles $(28.18 \%)$, phyllosilicates $(10.81 \%)$ and quartz $(8.75 \%)$. S type tonalite shows similar mineral mode regardless of horizons of intrusion (1-1 to 1-5 for basal tonalite, 3-1 to 3-5 for lower tonalite and 8-1 to 8-5 for middle). They are composed of quartz (30.52-32.12\%), plagioclase (32.14-39.20\%) and phyllosilicates (26.68-31.66\%).

The results of mineral mode analysis indicate that the S-type tonalite and pelitic gneiss are dominated by phyllosilicates and quartz, whereas other three lithofacies (amphibolite, hornblende diorite-tonalite and gabbronoritehornblende) are dominated by plagioclase, amphiboles and pyroxenes, and they contain a few amounts of phyllosilicates and quartz. We found from the results of detailed geological investigation that the localized mylonite zones developed preferentially in the S-type tonalite and pelitic gneiss, and less developed in hornblende tonalite, and few in gabbronorite-hornblende gabbro, troctolite-olivine gabbro and amphibolite (see Fig. 1). These results indicate that the localized mylonite zones were preferentially initiated in phyllosilicate- and quartz-rich lithofacies.

\section{Descriptions of Mylonite and Pseudotachylyte in Localized Shear Zone}

One of the best outcrops of localized mylonite zones is exposed along the Panke-river main stream (A in Fig. 1). Here, localized mylonite zone is roughly $50 \mathrm{~m}$ in thickness, trending NS, and gently dipping to the east. Mylonitic foliation becomes more conspicuous with closer to the core of the shear zone. No obvious boundaries are observed between host and mylonitic rocks. In center of the shear zones, well-developed mylonitic foliations are commonly observed (Fig. 3(a) and (b)). Microscopically, quartz and feldspars are reduced in amounts and served as larger crystals to be porphyroclasts in these mylonites (Fig. 3(d)). Matrix is mainly composed of micaceous minerals. Foliations are defined by arrangements of these micaceous minerals. The contents of phyllosilicate minerals in well-foliated mylonitic rocks are more increased compared to host rocks (Fig. 3(c), (d) and h), which shows similar occurrence with those described by Hippertt (1998) and Lonka et al. (1998). In strongly deformed mylonite zones, residual quartz clasts typically show elongated shape, which are composed of elongated finer-sized quartz grains (Fig. 3(e)). These quartz clasts are observed within $10 \mathrm{~m}$ from the core of the shear zone. The quartz grains show larger size and more polygonal shape at the margins of the shear zone. Fabric analyses clarified that sense of shear was dextral-normal.
It is commonly observed that the pseudotachylyte veins preferentially overprint the well-foliated mylonite zones (Fig. 3(a), (b) and (g)). The pseudotachylyte veins are generally less than $5 \mathrm{~mm}$ in thickness, associated with narrow (3 to $5 \mathrm{~mm}$ in thickness) cataclasitc zones at either side of pseudotachylyte veins (Fig. 3(f)). However, single pseudotachylyte vein can be traced more than $10 \mathrm{~m}$ in length along its strike. Microscopically, the clasts involved in pseudotachylyte veins are extremely fine grained (1 to 10 $\mu \mathrm{m})$ by comminution and wearing, showing no evidence of dynamic recrystallization by plastic deformation. These observations indicate that seismic slip events occurred at seismic brittle regime, overprinting pre-existing heavily deformed, well-foliated mylonite zones. Similar occurrence of localized mylonite zones and pseudotachylyte veins are also observed along Simono-sawa stream (B in Fig. 1, Shimada et al., 2004).

\section{Discussion and Conclusion}

In southern $\mathrm{HMB}$, metamorphic and intrusive rocks were laid under the condition of amphibolite facies at the peak metamorphic stage (Fig. 4, Shimura et al., 1997). Мylonitic deformation occurred under lower green schist facies condition $\left(300\right.$ to $400^{\circ} \mathrm{C}$ ) based on the microscopic observations that feldspars are fractured to be porphyroclasts and quartz shows clear evidence of dynamic recrystallization (Passchier and Trouw, 1996). Chemical breakdown of plagioclase into micaceous minerals would be favorably occurred under similar temperature condition (Fitz Gerald and Stünitz, 1993; Stünitz and Fitz Gerald, 1993). The estimated temperature condition corresponds to the zones within the brittle-ductile transition (Sholtz, 1988). Therefore, the localized mylonite zones were formed under retrograde metamorphic stage possibly due to exhumation of southern HMB (Fig. 4).

Considering the facts that (1) localized mylonite zones are preferentially developed in the S-type tonalite and pelitic gneiss and (2) these two rocks are dominated by phyllosilicate minerals and quartz, we conclude that initiation of localized mylonite zones are controlled by lithology, that is, the localized mylonite zones are preferentially initiated within phyllosilicates- and quartz-dominated lithofacies. This stage is referred to as "Initiation stage" for preparations of seismic rupture surfaces.

Even within a localized shear zone, mode of deformation of quartz is contrasting between the zone within $10 \mathrm{~m}$ from core of the shear zone and marginal part of the shear zone. Quartz clasts show elongated shape composed of finer elongated grains within $10 \mathrm{~m}$ from the core of the shear zone (Fig. 3(e)). It is well known that this type of fabric is formed by dynamic recrystallization at lower temperature and/or higher strain rate conditions (Masuda and Fujimura, 1981). The zone containing elongated quartz clasts roughly corresponds to that of reducing in amounts of plagioclase and increasing of phyllosilicate minerals. These facts suggest fluid-enhanced chemical reaction occurred during progressive plastic deformation, including breakdown and dissolution of plagioclase, and/or growth of phyllosilicate minerals, under lower temperature/higher strain rate conditions. The mylonitic shear zone would be narrower into $10 \mathrm{~m}$ 

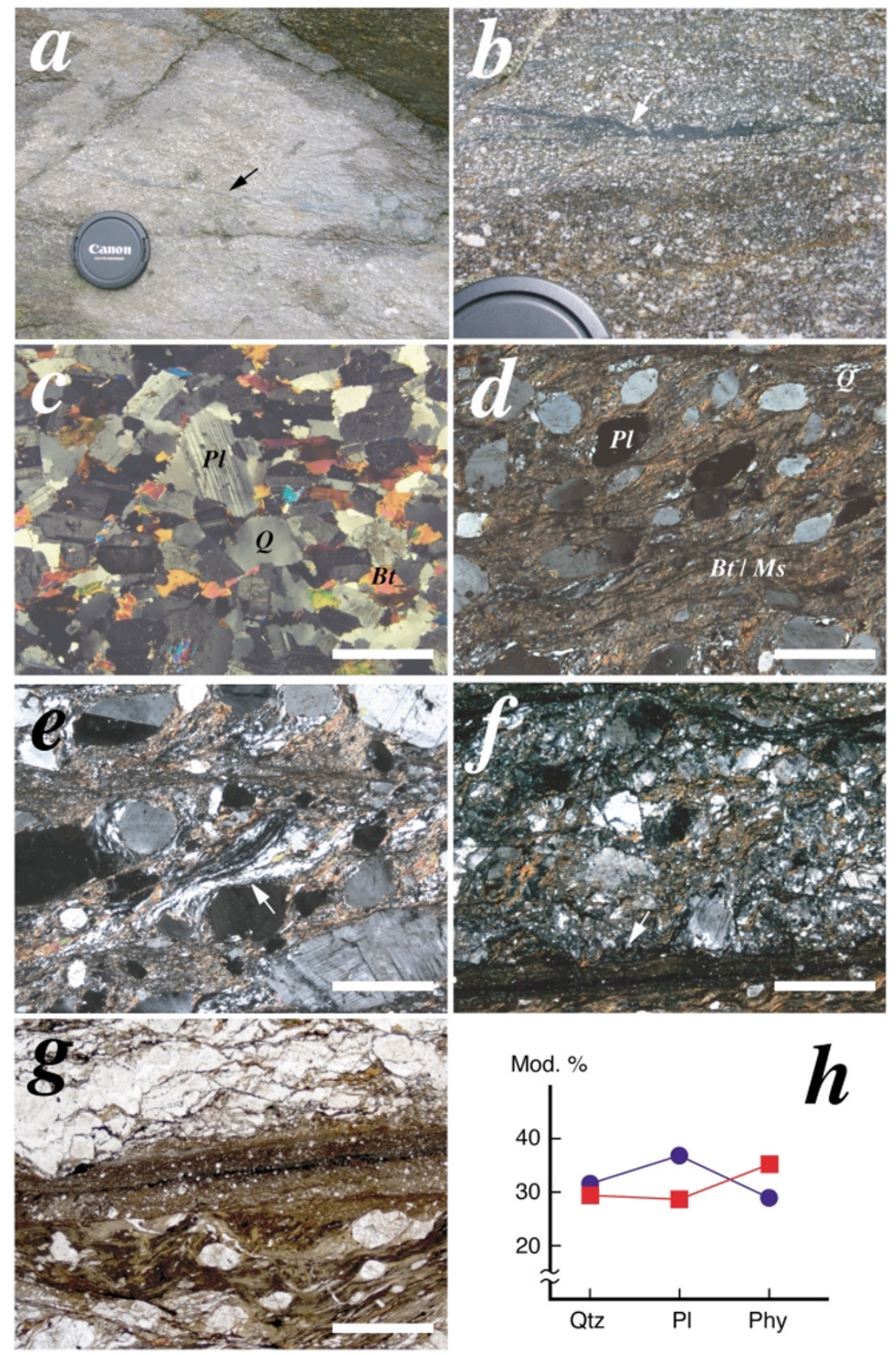

Fig. 3. Occurrence of mylonite and pseudotachylyte in localized shear zones. Bar scales in c, d, e and f: $1 \mathrm{~mm}$. Q: Quartz, Pl: Plagioclase, Bt: Biotite, Ms: Muscovite, (a) Thin pseudotachylyte vein (black arrow) runs parallel to the foliation of strongly deformed mylonite. (b) Close view of pseudotachylite vein (white arrow). The vein shows irregular boundaries and branches off to the north (left). (c) Occurrence of host rock (S-type tonalite). (d) Occurrence of strongly deformed mylonite. Note that a modal amount of phyllosilicate minerals is increased compared to host rock. (e) Occurrence of elongated quartz clast (White arrow). Quartz crystals in the clast are deformed plastically and elongated. (f) Brittle fractured zone are developed within $5 \mathrm{~mm}$ from pseudotachylite vein. The fractured zone is cut by pseudotachylyte vein (White arrow). (g) Occurrence of pseudotachylyte vein, which is the newest deformation within the whole localized shear zone. (h) Comparison of modal amounts of Quartz (Qtz), Plagioclase (Pl) and Phyllosilicates (Phy, Biotite+Muscovite+Chlorite) between host S-type tonalite (Blue circle) and strongly deformed mylonite (Red rectangle). Average values of modal composition of S-type tonalite (Table 2) is presented as a host rock modal composition.

in thickness. Probably, the phyllosilicate-rich mylonite was also formed under ductile-brittle transition condition, since little evidence of brittle failure was found within the phyllosilicate-rich mylonite, except overprinting pseudotachylyte, which will be discussed later. Timing of formation of the phyllosilicate-rich mylonite would be followed by, but possibly close to that of the mylonite formed at initiation stage, because larger strain is required to induce infiltration of fluids and chemical reaction than the mylonite formed at initiation stage. Temperature condition may be similar or slightly lower than that for the mylonite of the initiation stage. Phyllosilicate bearing rocks show frictionalviscous behavior and apparent coefficient of friction is inferred to be lowered to 0.25 to 0.35 at the seismogenic depth (Bos and Spires, 2002), suggesting that dynamic mode of deformation of the phyllosilicate-rich mylonite is largely different from mylonite formed at initiation stage. The lowstrength profile of the shear zone would be realized by initi- 


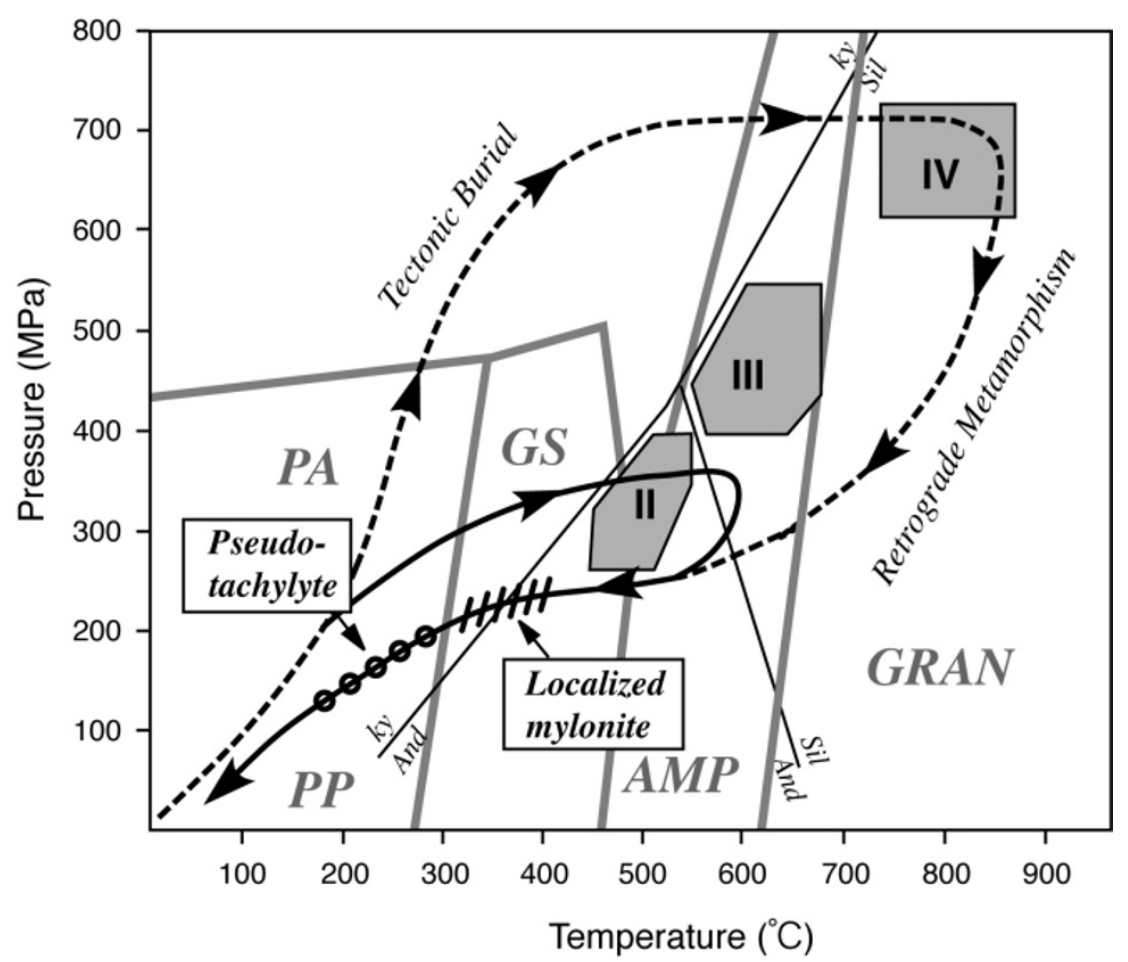

Fig. 4. P-T-t path of metamorphism in Hidaka metamorphic belt (Modified after Osanai et al., 1992). The path shown by solid line is appropriate for southern HMB (Osanai et al., 1991). See also Osanai et al. (1992) for metamorphic zones II, III and IV. Localized mylonite zones and pseudotachylyte veins overprinting mylonite zones were formed at almost final stage of retrograde metamorphism. GRAN: granulite facies, AMP: amphibolite facies, GS: green schist facies, PA: pumpellyite-actinolite facies, PP: prehnite-pumpellyite facies, Ky: Kyanite, Sil: Sillimanite, and And: Andalusite.

ation of localized shear zones in weaker (phyllosilicate- and quartz-rich) regions, and further by mechano-chemical positive feedback process of weakening (breakdown of plagioclase into phyllosilicates) within localized mylonite zones, as suggested by observations of localized shear zone in HMB. The positive feedback stage is referred to as "Promotion stage" for preparation of seismic rupture surfaces.

The pseudotachylyte veins are particularly concentrated within the narrow zones of heavily deformed mylonite being weakened by fluid assisted reaction. Microscopic observations indicate that they are generated by brittle failure and show no evidence of dynamic recrystallization. The deformation mode suggests that pseudotachylyte was generated under full brittle conditions. Similar occurrence of pseudotachylyte veins is observed along Shimono-sawa stream (B in Fig. 1, Shimada et al., 2004), where mineral veins containing prehnite commonly cut pseudotachylyte layers, suggesting that pseudotachylyte layers were generated under prehnite-related metamorphic conditions. The pseudotachylyte veins were presumably generated under prehnitepumpellyite facies conditions, since if we extrapolate retrograde P-T-t path from the stage of localized mylonite formation (Fig. 4) smoothly to the surface condition, it would pass through the PT condition around the boundary between prehnite-pumpellyite and pumpellyite-actinolite facies. Two types of pseudotachylyte veins are observed in $\mathrm{HMB}$. One is layer parallel type, which corresponds to the one described in this paper, and another is layer oblique type (Toyoshima et al., 2004). Toyoshima et al. (2004) describes that the former is commonly cut by the latter, and depth of generation of the latter was estimated to be around $4 \mathrm{~km}$
(Toyoshima, 1990). From these observations and discussions, we consider that the seismic friction slips occurred at around the bottom of the brittle crust $\left(120\right.$ to $\left.300^{\circ} \mathrm{C}\right)$, utilizing pre-existing well-foliated mylonite zones. The stage is referred to as "Generation stage". However, most of deformation experiments show stable behavior of phyllosilicate minerals under various $\mathrm{P} / \mathrm{T}$ conditions. (Logan and Rauenzahn, 1987; Bos and Spires, 2001, 2002). Fundamental mechanisms of generation of instability of phyllosilicate minerals still remain unclear. This problem should be clarified by future research. The sequence of deformation is in good agreement with the hypothesis that the deformation had occurred during exhumation of southern HMB. Considering P-T-t path of the HMB (Osanai et al., 1991, 1992), formation of localized plastic shear zones and pseudotachylyte veins seem to be almost final major events during whole metamorphic history of HMB (Fig. 4).

For summary of above discussions, we conclude that seismic slip surfaces had been prepared and finally activated through following three stages in the case of southern HMB. (1) Initiation stage: plastic deformation is localized preferentially within phyllosilicate- and quartz-rich lithofacies under the brittle-ductile transition condition. As a result, distribution of plastic shear zones is highly deviated and heterogeneous. (2) Promotion stage: Timing of this stage may be close to (1). Breakdown and dissolution of feldspars and quartz occurred associated with precipitation or grain growth of phyllosilicate by fluid-enhanced chemical reaction. Shear zone become narrower and weakened by strain softening. Constitutive behavior becomes frictional-viscous. (3) Generation stage: seismic, frictional 
layers were preferentially generated within weakest layers of strongly deformed mylonite zones under full brittle condition. Therefore in the case of southern HMB, the seismic slip surfaces had inevitably defined by heterogeneous distribution of lithofacies under the greenschist facies and higher $\mathrm{T} / \mathrm{P}$ conditions before exhumation to the seismogenic depth.

Acknowledgments. This study is supported by a grant for a comprehensive research program on "Flow and slip processes in and below seismogenic regions", sponsored by Ministry of Education, Culture, Sports, Science, and Technology, Japan. We also thanks to Mr. Mizuno, a secretary in chief of Samani town office.

\section{References}

Bos, B. and C. J. Spires, Experimental investigation into the microstructural and mechanical evolution of phyllosilicate-bearing fault rock under conditions favoring pressure solution, Jour. Struct. Geol., 23(8), 11871202, 2001.

Bos, B. and C. J. Spires, Frictional viscous flow of phyllosilicate bearing fault rock; Microphysical model and implications for strength profile, Jour. Geophys. Res., 107, 10.1029/2001 JB000301, 2002.

Fitz Gerald, J. D. and H. Stünitz, Deformation of granotoids at low metamorphic grade I: Reactions and grain size reduction, Tectonophysics, 221, 269-297, 1993.

Hippertt, J. F., Breakdown of feldspar, volume gain and lateral mass transfer during mylonitization of granotoids in a low metamorphic grade shear zone, Jour. Struct. Geol., 20, 175-193, 1998.

Komatsu, M., T. Toyoshima, Y. Osanai, and M. Arai, Prograde and anatectic reactions in the deep arc crust exposed in the Hidaka metamorphic belt, Hokkaido, Japan, Lithos, 33, 31-49, 1994.

Logan, J. M. and K. A. Rauenzahn, Frictional dependence of gouge mixtures of quartz and montmorillonite on velocity, composition and fabric, Tectonophysics, 144, 87-108, 1987.

Lonka, H., K. Schulmann, and Z. Venera, Ductile deformation of tonalite in the Suomusjarvi shear zone, southwestern Finland, Jour. Struct. Geol., 20, 783-798, 1998.

Masuda, T. and A. Fujimura, Microstructural development of fine-grained quartz aggregates by syntectonic recrystallization, Tectonophysics, $\mathbf{7 2}$, 105-128, 1981.

Obara, T., Structural analysis and petrological study of the Hidaka metamorphic belt in the Horoman-gawa River area, Unpublished master thesis of Niigata University, 1997 (in Japanese with English abstract).

Osanai, Y., M. Komatsu, and M. Owada, Metamorphism and granite genesis in the Hidaka metamorphic Belt, Hokkaido Japan, Jour. Metamor- phic. Geol., 9, 111-124, 1991.

Osanai, Y., M. Owada, and T. Kawasaki, Tertiary deep crustal ultrametamorphism in the Hidaka metamorphic belt, northern Japan, Jour. Metamorphic. Geol., 10, 401-414, 1992.

Osanai, Y., M. Owada, T. Shimura, T. Kawasaki, and B. J. Hensen, Crusta anatexis and related acidic magma genesis in the Hidaka metamorphic belt, Hokkaido, northern Japan, Mem. Geol. Soc. Japan, 47, 29-42, 1997 (in Japanese with English abstract).

Owada, M., Y. Osanai, and H. Kagami, Rb-Sr isochron ages for hornblende tonalite from the southeastern part of the Hidaka metamorphic belt, Hokkaido, Japan: Implication for timing of peak metamorphism, Mem. Geol. Soc. Japan, 47, 21-27, 1997 (in Japanese with English abstract).

Passchier, C. W. and R. A. J. Trouw, Microtectonics, Springer-Berlag, Berlin/Heidelberg, 289 p., 1996.

Shimada, K., H. Tanaka, T. Toyoshima, T. Obara, and T. Niizato, Occurrence of mylonite zones and pseudotachylyte veins around the base of the upper crust: an example from the southern Hidaka Metamorphic Belt, Samani area, Hokkaido, Japan, Earth Planets Space, 56, this issue, 1219-1225, 2004.

Shimura, T., M. Komatsu, S. Tsutai, M. Owada, and Y. Takahashi, Thermal and chemical interaction between granitic magmas and wall rocks in the Hidaka metamorphic belt, northern Japan, Mem. Geol. Soc. Japan, 47 1-12, 1997 (in Japanese with English abstract).

Sholtz, C. H., The brittle-plastic transition and the depth of seismogenic faulting, Geol. Runds., 77, 319-328, 1988.

Stünitz, H. and J. D. Fitz Gerald, Deformation of granotoids at low metamorphic grade II: Granular flow in albite-rich mylonites, Tectonophysics, 221, 299-324, 1993.

Toyoshima, T., Pseudotachylyte from the main zone of the Hidaka metamorphic belt, Hokkaido, northern Japan, Jour. Metamor. Geol., 8, 507523, 1990.

Toyoshima, T., Tectonic evolution of the Hidaka metamorphic belt and its implication in late Cretaceous-middle Tertiary tectonics of Hokkaido, Japan, Jour. Fac. Sci., Niigata Univ., Ser. E, 8, 1-107, 1991.

Toyoshima, T., M. Komatsu, and T. Shimura, Tectonic evolution of lower crustal rocks in an exposed magmatic arc section in the Hidaka metamorphic belt, Hokkaido, northern Japan, The Island Arc, 3, 182-198, 1994.

Toyoshima, T., T. Obara, T. Niizato, H. Tanaka, K. Shimada, M. Komatsu, and Y. Wada, Pseudotachylytes and related fault rocks from the Hidaka metamorphic belt, Hokkaido, northern Japan, Earth Planets Space, 56, this issue, $\mathrm{xxx}-\mathrm{xxx}, 2004$

H. Tanaka (e-mail: tanaka@eps.s.u-tokyo.ac.jp), K. Shimada, T Toyoshima, T. Obara, and T. Niizato 